\title{
An Exploratory Approach of the Mission Statement: Case of Saudi Arabia Business Schools
}

\author{
Fahad Al Olayan ${ }^{1}$, Wided Ragmoun ${ }^{2} \&$ Hanène Saidi $^{2}$ \\ ${ }^{1}$ Department of Tourism and Hotels Management, College Tourism and Archaeology, King Saud University, \\ Saudi Arabia \\ ${ }^{2}$ Department of Business Administration, College of Business and Economics, Qassim University, Saudi Arabia \\ Correspondence: Dr. Fahad Alolayan, Department of Tourism and Hotels Management, College Tourism and \\ Archaeology, King Saud University, Saudi Arabia. falolayan@ksu.edu.sa
}

Received: December 5, 2017

doi:10.5539/ijbm.v13n3p200
Accepted: January 22, $2018 \quad$ Online Published: February 25, 2018

URL: https://doi.org/10.5539/ijbm.v13n3p200

\begin{abstract}
Many studies on mission statements have applied one of three perspectives, those of components, stakeholders, and objectives, in their content analysis studies. This current study analyzed the mission statements of Saudi business schools by using the three perspectives together. Data were collected from 22 Saudi business schools' mission statements. The results show that Saudi business schools' mission statements are not well formulated, given that the majority of mission statements' objectives are totally absent, and the components and stakeholders are moderately mentioned in the studied missions. Drawing upon the three aforementioned perspectives, the results of this study provide business schools with valuable guidance to formulate accurate and effective mission statements.
\end{abstract}

Keywords: mission statement, Saudi business schools, content analysis, mission statement perspectives

\section{Introduction}

Contemporary companies perform strategic planning and formulate mission statements which are implicitly suggested (Bart, Bontis, \& Taggar 2001).Such a mission statement should reflect the originality of the business and its purpose (David, 1989; Drucker, 1973).The mission statement is an essential part of strategic and operational management for all business types: public, private, for-profit, nonprofit, small, medium, large, and multinational companies and all education institutions (William \& Kofli, 2012). Therefore, Boyer (1984) agrees that the school improvement process and acceptance within the community must begin with a clearly stated purpose, goals, and mission. In spite of the mission statement's importance, it seems that the majority of companies face difficulty formulating it adequately.

In light of the potential strategic role of the mission statement and the difficulty of its formulation, researchers, academics, and managers in developed countries have been trying for three decades to empirically explore its size and composition in all types of organizations. Scott, Jaffe, and Tobe (1993) found that a well-structured mission statement should be clear, short, and inspiring. (Brown, 1998) assert that coordination to craft mission statements transforms the workplace into one in which workers and teams can express themselves in their work and find significance beyond the task; the same holds true for institutions of higher education. Studies have shown also that a mission statement should have a clearly defined structure with accurate and understandable components (David, 2003). Indeed, these components were presented for the first time in the study by David \& Pearce (1987). These two writers have focused on eight key components of the mission statement, while other studies have asserted that the mission statement must contain nine components (David, 1989, 2007). Having relied on those studies, Bart et al.(2001) has developed a model mission statement containing 25 components. Furthermore, the content of a good mission statement has been investigated using three perspectives - components, stakeholders, and objectives - and it was found that this mission must contain twelve components ( Davis \& Glaister, 1994; Bart \& Tabone, 1999), ten stakeholders and four objectives(Bartkus, , Glassman, and McAfee 2004). Despite the importance of the mission statement as mentioned above, its content, and the role that it plays in the survival and success of all types of organizations, research investigating its content has been conducted in developed countries, and this content was analyzed using the components', stakeholders,' and objectives' perspectives separately. (David, 2003; David, 1989, 2007; Bart, 1998; Drucker, 
1973; Mullane, 2002; David, 2003; Bartkus et al, 2004). Also, all of the extant literature has used content analysis to study this concept (Bart, 1998). Very few studies in developing countries and especially the Arabic ones have investigated the mission statement's content. Thus, studies on the mission statement in higher education were limited to some developed countries by the use of only one perspective, drawn from the three studies cited above and the content analysis. This type of research is practically absent in the Arabic context. Therefore, this research will be performed in the Saudi business school context using an exhaustive approach based on the components', stakeholders', and objectives' perspectives. Thus, this article will present firstly the literature review on the mission statement, its characteristics, its content, universities' missions statements, and their perspectives. Secondly, the results of the mission statements' content analysis will be interpreted to give the appropriate recommendations for the studied business schools.

\section{Literature Review}

Mission statement is the basis for strategic planning and the strategy's implementation in all types of organizations and may be implicitly suggested in organizations ignoring the method to formulate a mission statement (Bart et al, 2001; Tofty \& Chatterjee, 2004). Indeed, the importance of implementing a mission statement in the organization had a rich history in public administration and management literature (Palmer \& Short, 2008). Also, the usefulness and benefits of the mission statement have been studied by several researchers (Piercy \& Morgan, 1994; Simpson, 1994). Hence, the mission statement was defined as a composition mentioning the purpose of the business. it distinguishes an organization from other similar firms (David, 1989). It should answer the following questions: What is our business domain? (Drucker, 1973) or which business are we? (Johnson, Scholes, \& Whittington, 2008). The efficient and informative answer to these questions demonstrates the professionalism of the firm, inspires confidence, and generates staff commitment (Drucker, 1973; Wickham, 1997). Baetz (1998) and Rigby (1994)suggest that the right mission must perform the following actions: 1) Ensure the unanimity of a business, 2) Encourage positive feelings toward the company, 3) Assist a company in the right direction of the company, 4) Provide the basis of the objectives and strategies, 5) Serve as a focal point, and 6) Unify divergent opinions. The mission statement is also considered as an important tool for internal communication. It reflects the image and the uniqueness of a company that allows its employees to take ownership of the shares, uses its resources appropriately, and adapts to different environmental circumstances (Lynch, 2000). Obviously, a firm formulates a mission statement for several reasons: (1) as the most important managerial tool deployed by top management. (Bart et al, 2001); (2) it serves as an important tool for strategic planning and for the implementation of the strategy (Palmer \& Short, 2008); (3) its crucial impact on strategy and on organizational performance (Pearson \& David, 1987); and (4) it serves as a communication tool. Its role is to communicate the organization's strategy to stakeholders and guide strategic planning (Sufi \& Lyons, 2003; Batkus et al, 2004) Thus, the mission statement is very important for the motivation and the inspiration of employees (Batkus et al, 2004). Empirically, Mullane (2002) validates the important and the usefulness of the mission statement for daily practice operations, in contrast to other researchers who claimed that the mission statement is only an archaic paper serving as a wall hanging. Key components were presented for the first time in Pearce \& David (1987) work. The authors have focused on eight key components of the mission statement, while other studies have shown that the mission statement should contain nine components: consumers; products and services; market; technology; the concern for survival, growth, and profit; philosophy; public image; employees; and distinctive competencies (David 1989, 2007). However, Mullane (2002) explained that the components of the mission are not the most important aspect, but rather the process used to prepare and finish the mission document. Having relied on this research, Bart et al. (2001) constructed a model of a mission statement containing 25 components, as there was no consensus on the essential components of the mission statement and those unnecessary to avoid, and each researcher insisted on fixed components. Furthermore, the content of a good mission statement has been investigated using three perspectives: those of components, stakeholders, and objectives. It has been found that this mission must contain twelve components (Davis \& Glaister, 1994; Bart \& Tabone, 1999; Bartkus et al., 2004), ten stakeholders (Barktus et al., 2004; 2006), and four objectives (Bartkus et al., 2006).

In addition, the majority of previous researchers have investigated mission statements using content analysis (Bart, 1998). Thus, some recent studies emphasize an excellent and efficient way to define and implement the missions in the enterprises, universities, and hospitals (private and governmental) (Costel Esi, 2014; Bolt \& Douglas, 2005).

Indeed, the most recent studies on the mission statement have focused on how managers and leaders in developed countries formulate the mission statement using only one perspective from the three cited above, and its degree of comprehensibility. While there was negligence of investigating the mission statement in the 
organizations operating in developing countries (William \& Cofe, 2012; Desmidt et al., 2008).

To conclude, the mission statement offers several advantages, as mentioned above and in several previous studies, conducted mostly in developed countries. However, we don't have sufficient understanding of the composition of the mission statements at university business schools in developing countries, especially Arabic ones, using a combination of the three mission statement perspectives (those of components, stakeholders, and objectives). Thus, we will approach this topic in the following section.

\subsection{Mission Statements in Universities and Its Content}

Universities as non-profit organizations should have mission statements that set strong links with society, offer education quality, increase its scientific contribution, and guide the community (Davis \& Glaister, 1997).

In the 1980s, higher education institutions were called to articulate their purposes and objectives through mission statements and strategic plans (Mackay et al., 1995).

The content of mission statements in general and at universities in particular has been analyzed from three perspectives, as presented below.

\subsection{The Components Perspective}

This perspective focuses on the components included in the mission statements: industry, services, desired public image, concern for satisfying customers/target students, concern for employees, geographic scope, values/philosophy, motivational message of excellence or unique identity, benefit to society, distinctive competence, future orientation, and academic objectives. (Davis \& Glaister, 1994; Bart \& Tabone, 1999; Barktus et al, 2004; 2006).

Previous studies examined mission statements in relation to the organizational results and found that six components must be included in a good mission: philosophy, self-concept, public image, location, technology, employees, and concern for survival.

On the other hand, the existing literature has revealed two other components, customer and product/service, which are regularly included in mission statements of poor performers (Pearce \& David, 1989; William, 2008).

According to our objective here, it is also important to mention specific stakeholders in a university's mission statement.

\subsection{The Stakeholders Mentioned in Mission Statements}

A university's mission statements should include employees, academics, administrators, society, students, other search institutions, other universities, the government, and graduates (Barktus et al, 2004; 2006). It is crucial for the university to focus on them to achieve strong integration and unity. The mission should refer to academics, administrative personnel, and also students to motivate them to align with the university's objectives, purpose, and reason in order to increase the efficiency of the university as a whole. Communicating with other universities and other research institutions when formulating the mission statements will allow cooperation when conducting research projects and exchanging knowledge. In terms of the government and society, the university will gain support and respond to their demands.

Concerning the most important stakeholders that a good mission statement must include, there is a consensus among many scholars (Drucker, 1973; Mullane, 2002; David, 2003; Bartkus et al, 2004) that this mission has to mention specifically important stakeholders, such as employees, society, customers, owners, and investors.

Also objectives must figurate in any university' mission statement.

\subsection{The Objectives Perspective}

There are four objectives of good mission statement: declare the direction of a firm, present the boundaries of an organization in terms of business activities to prevent the implementation of inappropriate operations, present organizational values or philosophy, and allow employees to make non-routine decisions. Finally, this mission must express a shared sense of purpose/view to motivate or inspire employees (Bartkus et al, 2006).

Three of the objectives mentioned above must be included in a good mission statement: present organizational values or philosophy, express a shared sense of purpose/view, and declare the direction of a firm. This importance is due to the strong link between those objectives and the employees' motivation and decision-making.

As we demonstrated, the employees are the most important stakeholders to be included in a mission statement (Drucker, 1973; Mullane, 2002; David, 2003; Bartkus et al., 2004), so we deduce that those objectives are also 
crucial and must be included in a good mission statement.

While the contents of mission statements in public, not-for-profit organizations as well as universities have been investigated widely in developed countries (Davis \& Glaister, 1997),and each author uses one of the three perspectives, especially the components' perspective Davis \& Glaister, 1994; Bart \& Tabone, 1999; Barktus et al, 2004; 2006). However, this kind of research is totally absent with regard to developing countries and especially Arabic ones. Therefore, in this paper, we aim to analyze the content of the Saudi business schools' mission statements using an exhaustive approach based on the three perspectives mentioned above, summarized in Table 1below.

Table 1. Content of each perspective of mission statement

\begin{tabular}{ll}
\hline Perspectives & Content \\
\hline Components & $\begin{array}{l}\text { industry, services, desired public image, concern for satisfying customers/target students, concern for employees, geographic } \\
\text { scope, values/philosophy, motivational message of excellence or unique identity, benefit to society, distinctive competence, } \\
\text { future orientation, and academic objectives }\end{array}$ \\
Stakeholders & $\begin{array}{l}\text { employees, academics, administrators, society, students, other search institutions, other universities, the government, and } \\
\text { graduates. } \\
\text { Objectives }\end{array}$ \\
& $\begin{array}{l}\text { declare the direction of a firm, present the boundaries of an organization in terms of values or philosophy, allow employees } \\
\text { to make non-routine decisions,and express a shared sense of purpose/view to motivate or inspire employees. }\end{array}$ \\
\hline
\end{tabular}

\section{Methodology}

The aim in this study is to explore the content of mission statements in Saudi business schools and establish guidelines for the definition of a mission statement. To do so, the content analysis was adapted to analyze 22 Saudi business schools' mission statements, which collected from the web sites of the studied Saudi business schools.as indicated in Appendix (1). Atlas Ts software with thematic analysis were used to carry out the content analysis. Next, the results will be presented to give the appropriate recommendations to the studied schools. The content analysis, which is a qualitative approach, is more appropriate, since it observes and analyses the data included in a message of written text. The appropriate analyst examines the rate of recurrence and importance with which words and main themes occur (Woodraw, 2006). Those mission statements were analyzed based on the three perspective as mentioned in Table (1).

\section{Findings}

The analysis of data is performed with reference to each mission statements' perspective, as presented below:

\subsection{Analysis of Saudi Business Schools' Mission Statements from the Components' Perspective}

As presented in Table (2) and Figure (1), the results revealed the first rated and prevalent component in Saudi business schools' mission statements is services $(25,100 \%)$. This component was defined at different levels of the analysis, which explains the number 25 , despite the fact that the number of studied schools is 22 . In other words, the component services were defined in different ways at the same school. For example, the services provided to employees and students were identified at the same time by the software used in this content analysis.

Secondly, the distinctive competencies $(18,81 \%)$, public image $(17,77 \%)$,and motivational message of excellence $(14,63 \%)$ are respectively the second, third, and fourth rated components. Additionally, customers $(11,50 \%)$ were featured in approximately half of the analyzed mission statements. Also, the analysis showed that the least important components in the analyzed mission statements are geographic scope $(6,27 \%)$, value/philosophy $(4,18 \%)$, and employees $(4,18 \%)$. Furthermore, mention of the industry occurred at a moderate rate $(12,54 \%)$ 
Table 2. Number of mission statements that include each component

\begin{tabular}{lll}
\hline Component & Number & Percentage \\
\hline Industry & 12 & 54 \\
Services & 25 & 100 \\
Public image & 17 & 77 \\
Customers & 11 & 50 \\
Employees & 4 & 18 \\
Geographic scope & 6 & 27 \\
Values/Philosophy & 4 & 18 \\
Motivational message of excellence & 14 & 63 \\
Benefit to society & 0 & 0 \\
Distinctive competencies & 18 & 81 \\
Future orientation & 3 & 14 \\
Academic objectives & 6 & 27 \\
\hline
\end{tabular}

\subsection{Analysis of Saudi Business Schools' Mission Statements from the Stakeholders' Perspective}

As shown in Table(3) and Figure(1), society is the stakeholder given the most importance in the studied mission statements $(9,40 \%)$. The two stakeholders of Saudi business schools that are given the second place are employees $(2,50 \%)$ and academics $(2,50 \%)$, and we noticed a total absence of administrators $(0,0 \%)$. Furthermore, students and graduates, which constitute the customers of business schools, are absent in the studied missions $(0,0 \%)$. Finally, families, other research institutions, and other universities were not included in the Saudi business schools' mission statements $(0,0 \%)$.

Table 3. Number of mission statements that include each stakeholder

\begin{tabular}{lll}
\hline Stakeholder & Number & Percentage \\
\hline Employees & 2 & 9 \\
Academics & 2 & 9 \\
Administrators & 0 & 0 \\
Students & 0 & 0 \\
Society & 9 & 40 \\
Other research institutions & 0 & 0 \\
Other universities & 0 & 0 \\
Government & 0 & 0 \\
Graduates & 0 & 0 \\
Families & 0 & 0 \\
\hline
\end{tabular}

\subsection{Analysis of Saudi business schools' Mission Statements from the Objectives' Perspective}

As is shown in Table (4) and Figure (1), the statistical results revealed that the objectives of presenting values or philosophy $(0,0 \%)$ and providing a sense of direction $(0,0 \%)$ are totally absent in the studied mission statements. The rate for the objective of inspiring and motivating employees is very low $(1,5 \%)$. Finally, the objective providing sense of direction is absent $(0,0 \%)$.

Table 4. Number of mission statements that include each objective

\begin{tabular}{lll}
\hline Objective & Number & Percentage \\
\hline Mission statement provides sense of direction & 0 & 0 \\
Mission statement is a control mechanism & 0 & 0 \\
Mission statement presents values or philosophy & 0 & 0 \\
Mission statement inspires and motivates & 1 & 5 \\
employees & & 0 \\
\hline
\end{tabular}



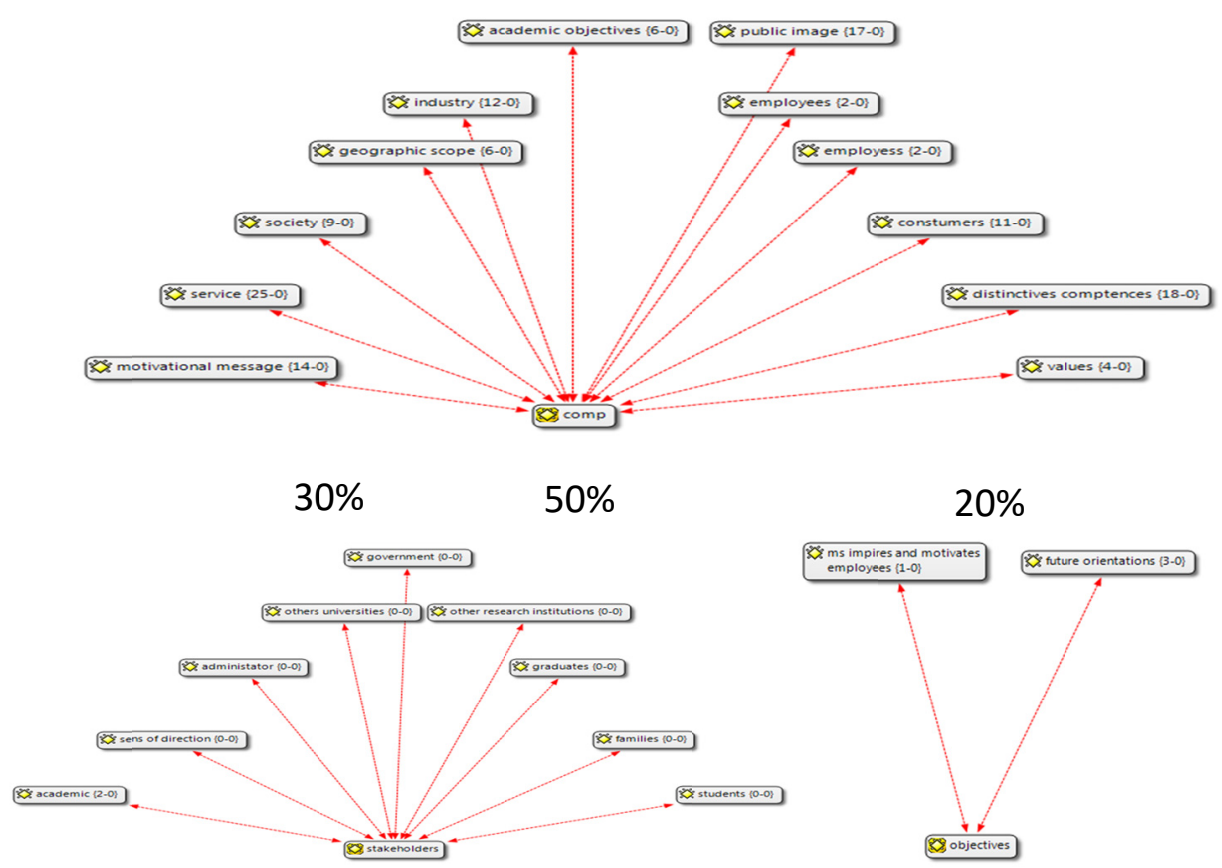

Figure 1.

\section{Discussion of Findings}

The study investigates the content of Saudi business schools 'mission statements from an exhaustive approach based on three perspectives, those of components, stakeholders, and objectives, and found that the researched business schools' mission statements are not crafted as should be. This is due to the absence of many important components, including stakeholders as well as objectives. More specifically, the study found that the studied mission statements of business schools frequently do not mention employees, administrators, and academics who support and develop the organization.

The research also revealed that, in spite of its low importance and contribution to the organizational success found in the previous studies, services are the most prevalent component of the studied mission statements.

In one of research revelations, customers were featured in approximately half of the analyzed mission statements in spite of its bad effect on the organizational benefits, as demonstrated in the previous researches. In addition, the analysis shows that the least important components in the analyzed mission statements are geographic scope, value/philosophy as well as employees which constitute a big disadvantage of the studied mission students because, as indicated in the literature review philosophy, employees, geographic scope are the most important components of mission statements that increase the organizational benefits. Furthermore, the distinctive competencies of public image as well as motivational messages of excellence are respectively the second, third, and fourth rated components. This is a strength for the studied mission due to the great value of those components and their contribution to the organization's success and evolution. The research found that society is the first rated stakeholder and is given the highest importance in the studied mission statements. According to its significance, the found society's rate is very low. Also, it is noticeable that, in spite of their mention in the literature review as very important stakeholders, students and graduates are absent in the studied missions. Finally, one of the study revelations is that the two objectives, presenting values or philosophy and providing a sense of direction, are practically absent in the studied mission statements, which constitutes a big disadvantage of the studied mission statements because those objectives are strongly linked with the employees' motivation and decision making. As demonstrated in previous studies, employees are the most important stakeholders in the organization. Furthermore, the objectives of inspiring and motivating employees has a very low rate of mention in spite of its importance and positive relation with employees' and the organization's effectiveness.

\section{Conclusions and Recommendations}

In general, the business schools' mission statements are not well formulated and need to be revised. More specifically, the majority of mission statements' objectives are totally absent, and the components and stakeholders are only moderately mentioned in the studied missions. Therefore, this study recommends that geographic scope, value/philosophy, and employees must be mentioned more often in the studied mission 
statements. Then the studied schools must concentrate more on distinctive competencies, public image, and motivational message of excellence due to the great value of those components and their contribution to the organization's success and evolution.

To improve their mission statements, Saud business schools should not mention the components of services and customers often. Also, they should include society in the greatest number of their mission statements, because its current rate of mention is moderate. Furthermore, they must concentrate more on employees, academics, and administrators and introduce these aspects in their mission statements. Furthermore, students and graduates must be included frequently in their mission statements to attract, motive them; and to encourage them to find jobs and build their own successful businesses. Additionally, studied mission statements must concentrate on the following objectives: presenting value/philosophy, providing a sense of direction, and inspiring and motivating employees. Consequently, this study may enhance the understanding of the mission statement formulation and help the studied schools revisit and improve their current mission statements. Furthermore, it might provide a basis for other research which explores the concept of mission statements using a quantitative approach and extend the future research to the relation of this concept with teaching performance, universities' performance, and organizational benefits.

\section{References}

Baetz, M. C. (1998). The relationship between mission statements and firm performance: An exploratory study. $J$. Mange. Studies, 36(6), 823-853.

Bart, C. K. (1998). The relationship between mission statements and firm performance: An exploratory study. $J$. Mange. Studies, 35, 823-853.

Bartkus, B. R., Glassman, M., \& McAfee, R. R. (2004). A comparism of the quality of European, Japanese and US mission statement: A content analysis. European Management Journal, 22(4), 393-401.

Bolon, \& Douglas, S. (2005). Comparing mission statement content in for-profit and not-or-profit hospitals: Does mission really matter. Hospital topics.

Bontis, N., \& Taggar, S. (2001). A model of the impact of mission statements on firm performance. Management Decision, 39(1), 9-18.

Boyer, E. L. (1984). Clarifying the mission of the American high school. Educational Leadership, 42(2), 20-22.

Brown, M. G. (1998). Improving your organization's vision. The Journal for Quality and Participation, 21(5), 18-21.

Costel, E. M. (2013). Performance and Excellence in Defining, Asserting and Concretizing the Mission of Business Organization. Social and Behavioral Sciences, 92, 323-327. https://doi.org/10.1016/j.sbspro.2013.08.679.

David, F. R. (2003). It is time to redraft your mission statement. J. Bus. Strategy, 24, 11-14.

Davies, S. W., \& Glaister, K. W. (1997). Business school mission statements the bland leading the bland? Long Range Planning, 30(4), 594-604.

Desmidt, S., \& Heene, A. (2003). Mission satements: In search for ameliorated performance through organization - employee value congruence. Ethics and Integrity of Governance, 1st workshop of the EGPA Study group, Oeiras, Portugal.

Drucker, P. F. (1973). Management: Tasks, responsibilities, and practices. New York: Harper \& Row.

Johnson, G., Scholes, K., \& Whittington, R. (2008). Exploring corporate strategy: Text and cases (8th ed.). London: Prentice Hall.

Lynch, R. (2000). Corporate strategy. Harlow: Pearson eucation.

Mackay, M., Scott, P., \& Smith, D. (nd). Restructured and differentiated? institutional responses to the changing environment of UK higher education. Higher Education Management, 7(2).193-205.

Mullane, J. V. (2002). "The mission statement is a strategic tool: when used properly. Management decision, 40(5), 448-455.

Palmer, T. B., \& Short, J. C. (2008). Mission statements in U.S. Colleges of business: An empirical examination of their content with linkages to configurations and performance. Acad. Manage. Learn. Educ., 7(4), $454-470$.

Pearce, J., \& David, F. (1987). Corporate mission statement: the bottom line. Executive, 1(2), 109-16. 
Piercy, F., \& Morgan, N. (1994). Mission analysis: an operational approach. Journal of General Management, 19, $1-19$.

Rigby, D. K. (1994). Managing the tools. Planning Review, 20-24.

Scott, S., Jaffe, D., \& Tobe, G. (1993).Organizational vision, values, and mission: Building the organizations of tomorrow. Thomson Crisp Learning.

Simpson, D. (1994). Rethinking mission and vision. Planning Review, 22, 911.

Sufi, T., \& Lyons, H. (2003). Mission statement exposed. Int. J. Contemporary Hospitality Mange., 15, $255-262$. https://doi.org/10.1108/09596110310482173

Tabone, C. J. (1999). Mission statement content and hospital performance in the Canadian not-for-profit health care sector. Health Care Manage. Rev., 24, 18-29.

Tofty, C. N., \& Chatterjee, J. (2004). Mission statements and the small business. Bus. Strategy Rev, 15(3), 41-44. https://doi.org/10.1111/j.0955-6419.2004.00326.x

Wickham, P. (1997). Developing a mission for an entrepreneurial venture. Management Decision, 35(5), $373-881$. https://doi.org/10.1108/00251749710173742

Williams, L. S. (2008). The mission statement a Corporate Reporting Tool With a Past, Present, and Future. Journal of Business Communication, 45(2), 94-119. https://doi.org/10.1177/0021943607313989

Williams, P. A. (1997). Developing a mission for an entrepreneurial venture. Management Decision, 35, $373-381$.

Woodraw, J. (2006). Institutional mission: The soul of Christian higher education. Christian Higher Education, 5(4), 313-327. https://doi.org/10.1080/15363750600860778

\section{Appendix A: Missions statements of Saudi Business Schools \\ Mission Statement number 1}

Dissemination of science in the field of administrative and humanities sciences through the adoption of programs and academic plans take into account the quality standards and accreditation for the rehabilitation of national cadres able to serve the community, and to fit the needs of the local labor market and regional levels.

\section{Mission Statement number 2}

The mission of the College of Business Administration is to prepare and graduate students with research and scientific capabilities featured in a stimulating academic environment which contributes in the overall development through the following :

- Attracting academically qualified faculty members.

- Administrative qualified leaders.

- Provide scientific programs with high academic quality.

- Conduct scientific researches that contribute in the development of society

\section{Mission Statement number 3}

Creating a distinctive educational environment to prepare business professionals and leaders with international perspectives; conducting research that contributes to the advancement of business knowledge and economic development; and building effective partnerships with local and global communities

\section{Mission Statement number 4}

The College of Business and Economics contributes to the society and the business community by developing graduates with current business knowledge and skills through relevant curricula, and encouraging the faculty to make continuous contribution to the knowledge base by engaging in business research

\section{Mission Statement number 5}

Scientific distinction in developing qualified cadres for future businesses through educational programs that comply with international standards, submitting researches, and specialized consultations that encourage knowledge, help to develop the national economy, and serve the society.

\section{Mission Statement number 6}

Adhere to the Business Administration College at the Ras governorate to provide academic programs of high 
quality and competitive nature, and to provide its graduates of knowledge and skills and values that enable them to engage in professional life and the highest standards of professionalism, and the provision of academic research and advanced applied serve scientific knowledge and economic development, and a partnership contract effective community with all strata of society.

\section{Mission Statement number 7}

FBA is committed to providing distinguished academic programs that will train and produce qualified graduates for the Saudi labor market and conduct high quality scientific studies and research that serve the local and regional communities.

\section{Mission Statement number 8}

Delivering excellent education in Management, MIS, Accounting, Economics and Finance, and producing innovative research work that takes business knowledge and practice into new frontiers.

\section{Mission Statement number 9}

The College of Business Management (CBM) committed to preserve excellence in its academic programs, research and community service through the following:

\section{Teaching:}

Preparing students with efficient knowledge in their field and with the skills necessary for the labor market, including self-learning and skills of leadership and teamwork.

-Constructing and using flexible study programs responsive to the needs of society and in particular to serve the pilgrims and visitors of Makkah.

-Recruiting highly qualified members of teaching while continuing to develop their skills and motivate them to stay on the job.

-Using modern technology and methods of self-learning in the educational process, and methods of thinking .

\section{Research:}

-Preparation of distinct theoretical and applied researches in accordance with worldwide research standards to serve the objectives of community development for private and public organization and individuals.

\section{Community service:}

-forming a partnership with business and civil society institutions such as: Pilgrims oriented establishments, and local non-governmental organizations in the community.

-Providing quality services to the community, and contributing to solve the problems it faces .

-Offering continuing education programs at vocational and academic levels for the students obtaining bachelor degree and as well as employees at Pilgrims oriented establishments.

-Offering advisory services to the businessmen, civil society institutions and non-governmental organizations in the community surrounding the university.

-Providing ongoing support to the university administration and helping it in decision-making, as well as contributing in developing the university community.

-Making the data base of the college available to the community surrounding the university.

\section{Mission Statement number 10}

- Providing the best scientific programs in business administration to prepare qualifications meet the needs of the market and contribute to the achievement of comprehensive development in the light of Islamic values. Production and support of scientific and applied research that contribute to enrich the knowledge and achieving development goals

The development of an effective partnership with the community to improve the business environment and contribute to building a knowledge society.

\section{Mission Statement number 11}

Preparation of specialized skills in the field of business that is characterized by leadership abilities, entrepreneurial spirit and moral values and focus on applied research, which would contribute in establishing a community partnership

\section{Mission Statement number 12}


The mission of the college is to establish excellence in business education and research by providing a challenging academic environment that fosters learning and empowers our students with the skills required to become leading professionals in the field of management science.

\section{Mission Statement number 13}

Create educational and research environment in the field of finance and business to serve the community

\section{Mission Statement number 14}

Providing an academic and practical environment involved in community service and enrich the outstanding cadres of the labor market in the areas of administration and home economics

\section{Mission Statement number 15}

College committed to producing specialized Knowledge in finance and business through scientific research and the outstanding graduating qualified who are able to re-produce knowledge in pursuit of human service and the business environment

\section{Mission Statement number 16}

Provide corporative educational services that achieved an academic and technological environment for high quality teaching, and provide a community contribution lead to advancement of society and its development.

\section{Mission Statement number 17}

Our mission is to create a conducive academic environment to promote excellence in business education, research and service towards community through commitment to quality and persistent improvement in accordance with international standards.

\section{Mission Statement number 18}

College of Business Administration at Al-Kharj endeavors to develop principled, innovative and competent business professionals in an environment of academics, research, and community partnership. This is accomplished through the alignment with national and international academic standards

\section{Mission Statement number 1}

The COB in Rabigh strives to achieve compatibility with other higher education institutions by offering outstanding learning programs to equip students with necessary Attitudes, Skills, and Knowledge to succeed in diverse business environment.

\section{Mission Statement number 20}

Faculty of Economics and Management is a multi-disciplinary educational institution working on bachelor's and master's students Service by Regular full-time and part-full-time, in addition to professional staff. Therefore, the college is committed to achieving the following:

-Provide its graduates with the knowledge, skills and values that enable them to carry out their professional of the highest levels of professionalism.

-Enable faculty members to conduct theoretical and applied research, which would contribute to the enrichment and development of knowledge and provide innovative solutions to the problems facing the government and commercial sectors.

- Increase the contributions of faculty, staff members and students in order to improve the community, businesses, and government agencies at the local and national levels. This is achieved through the provision of specialized studies, consulting, and training programs geared to suit the needs of each group.

\section{Mission Statement number 21}

Providing scientific and practical knowledge in the areas of administrative, financial and intellectual upgrade levels for students by providing all the research and advisory services and training. And design programs of study are consistent with the mission of the university in the framework of Islamic values.

\section{Mission Statement number 22}

FBA is committed to providing distinguished academic programs that will train and produce qualified graduates for the Saudi labor market and conduct high quality scientific studies and research that serve the local and regional communities. 


\section{Copyrights}

Copyright for this article is retained by the author(s), with first publication rights granted to the journal.

This is an open-access article distributed under the terms and conditions of the Creative Commons Attribution license (http://creativecommons.org/licenses/by/4.0/). 